\title{
8. Moving Objects: The Case of Volvo
}

\author{
Bo Florin
}

\begin{abstract}
In 'Moving Objects: The Case of Volvo', the concept of mobility is investigated on several levels - the movement of the cars, the movement of people, and the movement of the camera - and how this concept is launched within the ads along with 'Scandinavian' values. The commercials also point back to the basic definition of cinema qua moving images, aiming in turn at moving the audience.
\end{abstract}

Keywords: cars, mobility, movement, Volvo

In the history of advertising film, cars have played a pivotal role as advertised objects for many decades. However, in comparing print and moving picture ads for cars, it is striking that, whereas print ads in general seem to suggest mobility, advertisers in moving images have, on the contrary, frequently chosen to depict the cars as immobile objects. ${ }^{1}$

The very definition of cinema as moving images, perhaps the most banal but also the most general, adopted from early on, points to the fact that the ability to create movement in film has fascinated viewers from the early years of cinema and onwards. In his Images mobiles, Jean-Louis Schefer initially claims that amazement is the basic capacity of cinema. ${ }^{2}$ At the same time, he also notes that motors, giant machines, and other bizarre

\footnotetext{
1 See, for instance, the Un-Pimp Your Ride series for Volkswagen (2006); 'The Slowest Car We've Ever Built' for Audi R8 (2007); 'Human Car' for Ford (2008); ‘Change Perspective' for Saab (2009); 'Everything is Sport' for Renault Megane (2010); 'German Car' for Opel Astra (2012); 'Le meilleur, sinon rien' for Mercedes-Benz (2013); 'The Car That Answers Today's Questions' for Citroën C4 Cactus (2014); 'X' for Fiat 50oX (2014); 'Piggy Bank' for Toyota (2015). As for paper ads, see Bo Florin, 'Morfaus - ihmisestä moottoriksi' (Morphing - from man to motor), Lähikuva 4 (2001): 23-27.

2 Jean-Louis Schefer, Images mobiles (Paris: P.O.L, 1999), 17.
}

Florin, B., P. Vonderau, Y. Zimmermann, Advertising and the Transformation of Screen Cultures. Amsterdam: Amsterdam University Press, 2021 DOI 10.5117/9789462989153_CHo8 
mobile objects that frequently occur in early cinema - an art that, in many ways, constitutes modernity - are often used to equal humans; if cinema is a modern art, he argues, it is indeed in this capacity, that it registers and includes a number of objects, images, or sequences in its constant movement - and that cinema expresses the passing of time in reproducing human mobility, and 'inspiring feelings, suspense, fright, boredom, pleasure'. ${ }^{3}$ This ability to make objects move was also adopted early on in advertising films, which Michael Cowan observed in his analysis of Julius Pinschewer's animated films from the 1910s, in which he discusses how they, in showing products in movement, thus anthropomorphize commodities. Equalling human culture and its products in this way also sheds light on modernity, in which consumer culture and its products have gradually acquired 'an autonomous status'. ${ }^{4}$ Cars combine - with other technological means of transportation - the unique capacity of being mechanical objects with the ability to move. Automobiles, trains, or airplanes were thus cherished objects in early cinema, both in commercials and in other films. Later, however, as cameras became increasingly mobile, the concept of movement in film was extended to also creating movement by film - which creates a new tension between the movement within the frame and the movements of the frame itself, which opens for the new modes of mobility that the history of cinema has indeed explored in depth.

In the following, I will analyse the paradoxical relation between movement and arrest in car advertising through a number of Volvo film ads, in which the very name of the car - 'I am rolling' in Latin - suggests movement and mobility. ${ }^{5}$ To what extent is this expressed, and how do the ads address the concept of mobility? I will discuss the degree of mobility in connection with the degree of visibility of the car as object, and how the ads actually

3 Ibid, 235 .

4 Michael Cowan, 'Advertising and Animation: From the Invisible Hand to Attention Management', in Films That Sell:Moving Pictures and Advertising, ed. Bo Florin, Nico de Klerk, and Patrick Vonderau (London and New York: Palgrave, 2016), 99.

5 The archive of Volvo films and stills is kept by the Gothenburg company Frontema AB, on behalf of the Volvo museum archive. This archive contains around 5000 films, both industrial films and advertising films. Around 3000 of these films were made between 2000 and 2015; the remaining 2000 films were made between 1927 and 1999. Almost all of the films from the 1930 s are missing. The few remaining films from 1927 to the end of World War II are on nitrate. According to Peter Ohlson at Frontema AB, most of the films from the period would have been destroyed due to the risks of preserving nitrate films (personal email 20 November 2014). For a definition of industrial film, see, for instance, Vinzenz Hediger and Patrick Vonderau, eds., Films that Work: Industrial Film and the Productivity of Media (Amsterdam: Amsterdam University Press, 2009). 
communicate their message. Secondly, I will investigate the impact of the company's ownership ${ }^{6}$ and of ad agencies over time. In what ways - if any - do changes in ownership or of agency change the style and mode of address of the ads, and the ways of depicting mobility?

I have limited this study to cinema and television commercials, and my main source will be the commercials themselves. In addressing the theme of mobility, I have focussed on a few particularly significant films from each decade, thus also choosing a qualitative approach to the films rather than attempting to write a complete history of Volvo ads. Though my aim is not primarily historical, this analysis nevertheless inevitably contains a historical dimension, since the films discussed are made during several decades, from the 1940 s to the 2010s. The reason for this is that, when going through the archival material, I found that it contains a number of central themes that are repeated and varied throughout the decades, and which I attempt to deal with in the following: from general, denotative aspects relating to the car as such - car model, fuel consumption, safety - to more connotative "added values", such as national iconography and cars as lifestyle. In dealing with Volvo's history of different owners and different advertising agencies, the issue of national versus international in the modes of advertising is also inevitably brought to the fore. I am interested in how the films are made: in which kind of surroundings the cars are shown, and above all, which cinematic devices are used? My main focus thus remains with representational issues and cinematic techniques.

Since the early 19oos, two co-existing theories of advertising have competed on the market: the hard sell and the soft sell. Hard-sell advertising, according to early theorists such as John E. Kennedy, Claude Hopkins, or Albert Lasker, was what they called 'salesmanship in print'. In Juliann Sivulka's words, this means that one should 'state in print what a salesman would have said in words to a customer. That is, it should offer a sensible argument with specific reasons why the product was worth buying.7 Applied to TV or cinema commercials, that could mean using both a spoken comment and a written text.

On the other hand, 'proponents of the soft sell', Cynthia B. Meyers writes, 'following such rival theorists as Theodore MacManus, appeal to

6 The Volvo Cars Company was owned by Aв Volvo (Sweden) until 1999. Then Ford Motor Company acquired the company; in 2010 the Zhejiang Geely Holding Group of China took over. 7 Juliann Sivulka, 'History: 1900-1920', in The Advertising Age Encyclopedia of Advertising, vol. 2, ed. John McDonough and Karen Egolf (London: Fitzroy Dearborn Publishers, 2003), 761 
the consumers' emotional needs. [...] They attract the consumer with clever concepts, puns, humor, and visually arresting imagery'.

These two kinds of advertising, which will also reappear in the following, may be clearly illustrated by a couple of Volvo commercials, each dealing with safety, a core value for Volvo according to The Advertising Age Encyclopedia of Advertising, which contains an entry on 'Automobiles', in which Volvo appears under the heading 'Selling Safety', and it is emphasized that '[s]afety has been a cornerstone of Volvo's advertising [...]'. ${ }^{9}$

This statement may be confirmed for example by a commercial from 1957 called 'A Golden V for Volvo' for Volvo P444 (agency unknown), in which eight seconds of the 6o-second commercial are exclusively devoted to advertising safety. A car is driving on a suburban road, and a lady with a dog is walking on the pavement. Suddenly, she moves to cross the street, but the car is quickly approaching. Then there is a close-up shot of the pedals, with the driver slamming the brakes, followed by another close-up of a wheel braking quickly. Finally, we see the car safely stopped and the lady with the dog crossing the street just in front of it - a mutual glance of understanding between the driver and the lady ends the scene. During the scene the voice-over states, 'The brakes of the new Volvo, with peak power, give you peak security'.

A second example appears in 'Lucky Guy' for Volvo V4o (42 seconds), made by Forsman \& Bodenfors in 1999. A man is walking on the pavement on a city street. He is wearing earphones (we can hear a reggae tune on the soundtrack) and he does not seem to take any notice of what is happening around him. Then there is a cut to a builder on scaffolding, laying bricks. Back to the man on the pavement, who - without noticing - hits an old lady with his backpack and makes a man on a Vespa roll over when he crosses the street. Then again there is a cut to the worker on the scaffolding high above the street. Just as the pedestrian approaches, a brick falls, but the man stops short; something has caught his attention, and the brick hits the ground just in front of him (he still doesn't notice). The subject of his attention is a car parked on the opposite side of the street. He walks away,

8 Cynthia B. Meyers, 'The Best Thing on TV: 1960 os Us Television Commercials', in Films That Sell: Moving Pictures and Advertising, ed. Bo Florin, Nico de Klerk, and Patrick Vonderau (London and New York: Palgrave, 2016), 176. It is not that the soft sell can't use words; MacManus's famous 'The Penalty of Leadership' ad for Cadillac only consisted of words (and no illustrations). It is rather a question of tone.

9 Jean Halliday, 'Automobiles', in The Advertising Age Encyclopedia of Advertising, vol. 1, ed. John McDonough and Karen Egolf (London: Fitzroy Dearborn Publishers, 2003), 113. 
out of the frame, and leaves the car in focus. The closing text appears: 'Volvo V40. Designed to save lives.'

Not only do the two films deal with advertising in different ways, using hard sell and soft sell respectively, but there are obviously many other differences between the two commercials. They are made at different times, when the dominating cinematic devices also differed; they are made under different ownerships; they are made for a national and an international audience, respectively; in the first, the word safety is used literally, referring to the brakes of the car, whereas the second uses the term metaphorically; and last but not least, while the first film shows a car in quite dramatic motion, the car in the latter is parked alongside the pavement. Still, movement is equally important in this second film, which points back to the hypothesis mentioned initially, and which will be further explored in the following, that the focus of mobility in these ads is gradually shifting from the movement of the car as such to other kinds of movement within the image as well as to the movement of the image as such.

\section{Cars, Nation, and Lifestyle - An Iconography in Movement}

Among the most high-profile recent Volvo films was the 2014 Volvo advertising campaign 'Made by Sweden', featuring famous football player Zlatan Ibrahimović, later followed by 'Made by Sweden - prologue' and 'Made by Sweden - epilogue', both from 2016. Made in the north of Sweden, the 2014 ad centres on adventures in the wilderness: we see Ibrahimović diving into a hole in the ice, running, hunting deer, and sitting by the fire. And we see the car - Volvo $\mathrm{XC}_{70}$ - in this wild landscape, often from a distance. The film lasts for two minutes and contains no fewer than 75 shots. Of these, cars only appear in 20 shots (the logo included). Thus, the film suggests movement and speed, but less through the car than through the editing. In several shots, the car is actually stationary. Interspersed with pictures of the cold and of wild nature, there are on the one hand images from Ibrahimovićs home - his wife looking through a window as if longing for her husband outside, but also of them together in bed, or of Ibrahimović playing with his children - and on the other hand footage of Ibrahimović playing football for Sweden. All of this is accompanied by Ibrahimovic 's voice, reading a slightly changed version of the Swedish national anthem to music produced by Max Martin. In its evocation of mobile life, this film places itself at the heart of the matter. 
In the earlier history of Volvo ads, there is both movement and arrest. Cars are shown driving to demonstrate good traction or efficient brakes. Alternatively, the cars remain still, and the film focusses on comfort, the capacity of the boot, or the spacious interior, instead using the movements of the camera to create a sense of mobility.

Two films from the early 1970s, both directed by Bo Widerberg, may serve as examples here. In the first, 'Sauna' (1972), a parked Volvo 140 appears for a short moment in a story about an older man enjoying a sauna. The car then reappears in the last shot of the film. The voice-over - by actor Max von Sydow - is talking about life expectancy, of Swedes and of Volvo cars, and that the Swedish passion for fitness may be the reason for the Swedes' longevity. Volvo cars, like all Swedes, also have long lives, because, as the slogan explains, 'We build them the way we build them because we have to'. From the immobile car to human movement in a demonstration of a 'passion for fitness', the connection made in the voice-over commentary between passion for fitness and longevity is transferred from human to vehicle. In other words, the car will similarly live a long life, as it is built according to 'fitness' principles. In 'Cost of Living' (1972), cars are shown by means of paper ads. A little girl is sitting at a table, drawing. Beside her sits her father, taking care of family finances and looking into paper ads for cars, whereas the mother is busy putting groceries into the refrigerator. Max von Sydow, in voice-over, talks about the high cost of living and the need for financial planning, especially when it comes to buying a car. Thus, the durability of the car is particularly important. At the same time, a paper ad for Volvo comes into focus. The film again ends with the comment: 'We build them the way we build them because we have to.' According to the voice-over, it is worth it for the family, who are about to buy a new car, to choose a Swedish car, a Volvo, as this means that it will last for many years in the Swedish climate. ${ }^{10}$ The family is impressed by the pictures of the new seats, which have little to do with movement. In this ad, thus, there is no actual car, but only an image within the film image of a car. This ad within the ad, this mise en abyme, introduces a meta perspective to the film - a virtual movement from the ad depicted in the film to the actual film ad.

10 Without any explicit reference, this lines up with the classic slogan launched in 1944 by CEO Assar Gabrielsson: Volvos värde varar ('the value of Volvo lasts'). This slogan was actually still in use into the 1970s. 
In his two-volume book on the image of Sweden and Swedishness in the United States, Jeff Werner devotes a chapter to the Swedishness of Volvo. ${ }^{11}$ Here, he discusses Hanne Niss's general research on the importance of nationality in marketing. ${ }^{12}$ According to Niss, national signifiers are often used by new companies seeking to benefit from concepts associated with the nation. Werner notes that this also summarizes well the way in which Volvo was using concepts such as 'Swedish quality', 'Swedish craftsmanship', or 'design' during the first ten years of advertising. ${ }^{13}$ Werner's chapter focuses only on print ads, but I would claim that his study is equally valid for commercial films.

Hanne Niss's argument is also relevant for early Volvo commercials. However, it is not possible to extend her point, on new companies specifically using the nation as trademark, to a later period in time. On the contrary, Sweden has recently returned as a featured component in Swedish-produced Volvo advertising, not least through the Zlatan Ibrahimović films. Forsman \& Bodenfors, the agency behind the campaign 'Made by Sweden', started their Volvo campaign with the slogan 'Made by Scandinavia' (2012), in a similar manner referring to Scandinavian nature, but without any focus on celebrity. ${ }^{14}$ After this rather broad Scandinavian view, the agency has gradually sharpened its focus. In later print ads, the focus is further narrowed to Swedish landscapes: 'Made by Gästrikland' and 'Made by Södermanland', for example. In the film 'Made by Sweden', Swedish wilderness, Ibrahimović, and cars have been the producer's keywords. Forsman \& Bodenfors writes:

Together with Zlatan Ibrahimović we have done a celebration to Sweden. It's our country's unique nature that inspires and challenges the people at Volvo when they develop their cars. It's also here, at home, in the magnificent wilderness that they find their strength. Just as Zlatan does. ${ }^{15}$

11 Jeff Werner, Medelvägens estetik, Sverigebilder i USA, Del 2. (Hedemora: Gidlunds förlag 2008), 173-209.

12 Hanne Niss, Made in Denmark. Nationalitetens betydning i international marknadsføring (Aalborg: Aalborg Universitetsforlag 1994).

13 Werner, Medelvägens estetik, 189.

14 Forsman \& Bodenfors work with paraphrases, not only of the national anthem. Here, on the soundtrack, a child reads a paraphrased version of 'He's got the whole world in his hands': 'You've got the whole world in your hands'. With 'You've got you and me in your hands', the traditional Volvo focus on safety becomes quite apparent.

15 'Made by Sweden feat. Zlatan', http://www.fb.se/work/volvo/made-by-sweden (last accessed 6 April 2021). 
And along with the ad on Volvo's YouTube site the text reads:

Sweden is our home. Mountains, vast forests, long distances, sun, rain, darkness, snow and ice. This inspires and challenges us when we develop our cars. The Swedish wilderness is our heritage and it is here we find our strength. Just like Zlatan Ibrahimović. This is our celebration of Sweden. ${ }^{16}$

The fact that Ibrahimović reads the national anthem in the film quickly attracted commentary, as he has never taken part in the singing of the anthem with the Swedish national team. The words of the national anthem, however, are also changed in the Volvo ad: whereas the original refers to living and dying in 'the North' (Norden), this changed to 'Sweden' in the Ibrahimović film. This change also became a subject for heated debate in Sweden, as it was interpreted as an expression of a new nationalism. ${ }^{17}$

Interestingly enough, the image of a wooden cabin or a sauna in the film clearly parallels the already mentioned in 'Sauna' by Widerberg. Both of them evoke a Swedish or Nordic iconography, with the sauna in a winter landscape. I will return to this type of intertextual connection between different advertising films later in this essay.

The film 'Made by Sweden feat. Zlatan' was significant in its turn to celebrity as a way to market Volvo cars. As has already been noted, only 20 of the 75 shots in the film actually show the car. Another important aspect is the audible quality of cars. Hearing the car when it is out of sight could be an alternative way of featuring the car. In this ad, there are no car sounds when the car is not visible, and we can barely hear the sound of the car even when it is visible (because of the voice-over and the music). ${ }^{18}$ The majority of the images exemplify instead what may be called lifestyle images: the wild life with hunting, the home life with the family, and so on.

This is parallel to a development Jeff Werner traced in print ads; he notes that an increasing proportion of ads from the turn of the millennium onwards tend to be general 'lifestyle pictures', rather than specifically product related, to the extent that

16 'Volvo XC70 feat. Zlatan - Made by Sweden', https://www.youtube.com/watch?v=cbvdzQ7 uVPc\&list=PLnQowESnmpOfNzpaEc-r2LBeKsVtJkJxx\&index=3 (last accessed 6 April 2021).

17 DN 2014-01-28; $S v D$ 2014-01-28.

18 This is an important aspect, which could also be elaborated on a more general level. Due to the limited format of this study, however, I have chosen to omit it here. 
there are no pictures of cars whatsoever. The models are instead presented separately, in compositions with emphasis on luxury and speed. People reappear in the images, but they are no longer staged as car drivers or car owners. Instead, it is adults and now again often children who appear in attractive environments, engaged in tempting activities. Strikingly often, they are at the seaside. ${ }^{19}$

Here, though, almost all films differ from the print ad: the cars are still present, though framed through celebrities and their lifestyles.

In 2013, Forsman \& Bodenfors produced 'Leave the World Behind', which connects the so-called supergroup Swedish House Mafia, and their decision to stop touring, to Volvo XC6o: 'a cross-country car that can take you far away from the stressful city life'. ${ }^{20}$ The company also developed 'Made by Sweden' into a series, featuring different Swedish celebrities. Another 2014 film features the famous Swedish artist Robyn driving around after a day at work in Los Angeles, but also shows glimpses of her summer home in Sweden. This was followed by 'A Winter's Tale' (2015), a four-minute ad from different parts of Sweden featuring the song 'En vintersaga' by Ted Ström (1984) - a song that actually includes the line 'A lonely Volvo struggles in the headwind on the Tjörn Bridge' - and capturing the melancholy season. Featured celebrities include former hockey player Börje Salming; singers Timbuktu, Oskar Linnros, and Amanda Bergman; high jumper Emma Green; and fashion designer Carin Rodebjer. ${ }^{21}$

This celebrity trend - sometimes more local, sometimes more international - can also be traced in the earlier historical material. An ad for Volvo PV444, 'A New Star' (1947), opens with images of Greta Garbo and Ingrid Bergman, who are introduced as 'Swedish stars'. This is followed by an image of 'a new Swedish star': Volvo, which in turn is linked to 'Swedish beauty and style', accompanied by images of the Carl Milles fountain at the KTH Royal Institute of Technology campus and glass art from Orrefors. The film concludes that this beauty and style are 'qualities that have often won the day in global competition'. Though these earlier ads, both Swedish and international, emphasize the properties of the car - for example, the ad 'A Swedish Beauty' (1947) points out that the Volvo PV444 is spacious and

19 Werner, Medelvägens estetik, 185 .

20 'Leave the World Behind', http://www.fb.se/work/volvo/leave-the-world-behind (last accessed 6 April 2021).

21 Because of the length of the film, it is often shown in shorter pieces with only one celebrity at a time. 
fast, with low fuel consumption - they also link it to lifestyle and celebrity: excursions, sleepovers, and the like come into the picture, with the car as the vehicle for these seemingly endless possibilities.

Interestingly enough, the references to celebrities closely follow the pattern outlined above in connection to the question of the national. The national stars also return in a big way a decade into the new millennium, whereas they seemed to have disappeared by the mid 1960s in national ads, as the general references to Sweden declined. Internationally, however, there is no such trend; here, Swedishness has remained an important topos throughout the decades.

\section{A Changing History: From Proprietors to Agencies}

In 1999, Volvo was bought by the American-owned Ford Motor Company. It would be easy to assume that this would mean a radical change of strategies in advertising the car. However, head designer Peter Horbury, who had been hired by Volvo already in 1991, stated around the millennium that 'ii]t is important that the roots are Swedish. We will continue to emphasize the feeling for light, functionality, and timelessness that is found here. We make a Swedish car. ${ }^{22}$ Furthermore, Werner quotes a Q\&A for sellers from the period:

Q: I know Volvo is owned by Ford. How much of this car is Ford-driven? A: The $\mathrm{S}_{40}$ (and all Volvo models) features true Scandinavian design. The new $S_{40}$ will be built in Ghent, Belgium. Ford is our parent company; yet we remain true to Volvo values of safety, quality, and environmental care. ${ }^{23}$

The question here is whether this is reflected in the film ads. When Volvo was first bought by Ford, the Volvo car was integrated into a general Ford advertising campaign (1999). Swedish journalist Lennart Pehrson writes:

The campaign underlines how Ford now increasingly integrates Volvo as one of several trademarks under a Ford umbrella. Beside Volvo, there are Ford, Lincoln, Mercury, Jaguar, Mazda and Aston Martin. At 9 pm, local time, Ford will show a two-minute long advertising film for TV audiences all over the world. The consumers in New Zealand will be the first to see the film, which then will follow the time differences towards the west, 
in a way that is supposed to remind of how the new millennium will be rung in. Ford counts on reaching 300 ooo households or approximately a billion consumers all over the world in one strike. ${ }^{24}$

On the soundtrack, there is no talk about cars, but only a song accompanying the visuals, 'Just Wave Hello', by then thirteen-year-old Welsh soprano Charlotte Church. It was written especially for the advertising campaign, and as Pehrson noted, Ford hoped that it would become 'the global national anthem' of the company. ${ }^{25}$ The Ford film, a piece in slow motion but constant movement, shows people together, across all continents around the globe. They meet in various connections and situations, and between generations: a wedding, a deathbed, a newborn baby with her mother. They are people that meet or just pass by, people embracing, laughing and dancing, people performing rituals or stretching out their arms, celebrating freedom and liberty (one of them standing on a car, another sitting in one). During the whole film, there is sun and music, 40 shots of cars are quickly inserted - only nine of them in motion, while the rest stand still - all of the different types of cars owned by Ford. Each logo is visible once, and only the Ford logo reappears on several occasions. Thus, thanks to Ford, not only cars but also people from many nations are happily united - and thanks to the different cars, mobility and meetings are facilitated across the globe. The constant movement of the camera takes up the movement of the car in the first shot, caught through the image of a hand on a rear-view mirror in an otherwise blurred picture, which introduces human movement as the third part in this circulation between different kinds of movements and mobilities.

In the United States, the film was shown simultaneously on 38 different TV channels, including the largest broadcasters ABC, NBC, and CBS, and in Sweden, it was shown on cable channels such as CNN International, Discovery, MTV, and Eurosport. But it turned out that this campaign would remain exceptional, and the increasing integration predicted by Pehrson never really took place. Rather, it is striking that, apart from this singular attempt, advertisements for the Ford Company continued to be separate for each particular type of car. With Volvo ads, it was thus back to business as usual - but with a renewed focus on Sweden and Scandinavia.

In 2019, Zhejiang Geely Holding took over Volvo from Ford. At that point, there were no attempts similar to that of the early Ford ad to integrate

24 Ibid.

25 Lennart Pehrson, 'Bilindustrin: Volvo med i Fords 200o-kampanj. Tv-reklam ska stärka det amerikanska företagets varumärken', DNEkonomi, $3_{1}$ October 1999. 
Volvo into the company's overall profile. The changes in ownership thus turn out to have had only a minor influence on the way that the car has been advertised. ${ }^{26}$ Rather, the new owners have tended to emphasize the continuity and stability of the brand.

What, then, about changes in the advertising agencies used, nationally and internationally? In an essay on the history of Swedish trade and industry, business historian Oskar Broberg notes, '[a]lready in the 1920s, a couple of American advertising agencies had opened offices in Sweden, but they didn't last that long. Instead, it was during the 199os that the trade started to become truly international. ${ }^{27} \mathrm{He}$ describes the different strategies used by Swedish companies as they established themselves on an international market. Among the most successful were Forsman \& Bodenfors, who, according to Broberg 'established connections with globally active companies like Ikea and Volvo. These collaborations, in an otherwise very changeable trade, would turn out to be long term and important for the future development of the companies'. ${ }^{28}$

Internationally, the changeability of the trade is quite visible in the case of Volvo advertising, especially in the start as Volvo entered the us market in $1955 .{ }^{29}$ Little is known, however, about moving image ads from these early years in the United States. These years also marked the beginning of the so-called Creative Revolution, about which Cynthia B. Meyers writes:

In the late 1950s, the agency Doyle Dane Bernbach (DDB) designed an ad campaign since mythologised as the launch pad for the Creative Revolution. In one print ad, a black-and-white photograph of a Volkswagen Beetle the size of a coin appeared on a page of mostly white space, with the headline "Think Small'. The ad copy noted the advantages of 'small' insurance and 'small' repair bills and of being able to squeeze into 'small' parking spaces, implicitly mocking the excessive blustering of hard-sell claims of 'bigger, better.'. ${ }^{0}$

The revolutionary aspect of DDB's working method was to let copywriters and art directors work together, encouraging a more artistic way of advertising,

26 There are some exceptions to this general rule. In 2012, after the takeover of Volvo of a Chinese company from Ford, the American basketball star Jeremy Lin, of East Asian origin, signed an advertising contract with Volvo for ads in China and in the United States.

27 Oskar Broberg, 'Globalisering, entreprenörskap och humankapital', Det svenska näringslivets historia 1864-2014, ed. Mats Larsson (Stockholm: Dialogos Förlag AB: 2014), 628.

28 Ibid.

29 In 1955, Volvo entered the Us market, using Ed Belford Agency for advertisement purposes. In 1959, Anderson \& Cairns (later, Chirurg \& Cairns) took over for two years, but were replaced by Sind \& Sullivan in 1961, though only for six months.

30 Meyers, 'The Best Thing on TV', 177. 
often using irony to convey their message. The Volkswagen campaign also came up with a television commercial in a similar vein to the print ad described above. ${ }^{31}$

In 1962, Volvo signed with Carl Ally Inc., and remained with that agency until 1967. An article in AdAge notes that 'Ally moved Volvo onto TV and sharpened its durability theme with the promise that "Nine out of every 10 [Volvos] registered here [i.e., in Sweden] in the last 11 years are still on the road"'.32 It is obvious that Carl Ally was inspired by DDB - as were many other agencies during this time, and for many years to come. Carl Ally's first campaign for Volvo featured a car pushed to its limits by a rally driver. The ad starts with a close-up of the car's bonnet, and as a voice-over tells us that 'this is a Volvo, the Swedish-built compact', the engine starts to rumble and then the car goes with a flying start. The voice-over continues to describe the car as it drives on, very quickly, on a dirt road, raising a great deal of dust. The ad ends when the car suddenly brakes, and the camera zooms in on the logo at the back of the car. The campaign achieved much acclaim within the industry, and its slogans 'You can drive a Volvo like you hate it' (in the print ad combined with the price \$2565) and 'It's cheaper than psychiatry' became famous and placed Volvo on the us map. The ad has also been given new attention as it was part of a project, 'Re: Brief by Google', in which Amil Gargano, the art director of the ad, discusses it with younger colleagues. ${ }^{33}$

Volvo's first long-lasting relationship with an ad agency was with Scali, McCabe, Sloves, from 1967 to 1990 , though it was abruptly ended after a controversy concerning a commercial. ${ }^{34}$ One of their late commercials, 'Replacement Parts' (1990), stands out: the camera zooms out from a close-up on a rotating cranium and the text 'Cranium' appears. After that, the camera moves on, focussing on 'Lumbar Vertebrae', 'Scapula', 'Radius', 'Metacarpus', 'Thorax', 'Pelvis', and 'Metatarsus', each shot featuring - either in movement or with moving camera - the different parts of

31 'TV commercial film for Volkswagen “Think Small” HD', https://www.youtube.com/ watch?v=UUlZmZ_sd_E (last accessed 6 April 2021).

32 'Volvo', Ad Age, http://adage.com/article/adage-encyclopedia/volvo/98923 (last accessed 6 April 2021).

33 Project Re: Brief - Amil Gargano - Re-imagining Volvo, "Drive it Like You Hate it", https:// www.youtube.com/watch?v=RUHEyPtScıE (last accessed 6 April 2021).

34 'Scali's undoing was the "Bear Foot" commercial, filmed in Austin, Tex., in which a giant pickup truck with tires nearly as tall as a man crunched its way across a line of cars, flattening all but a Volvo station wagon. The advertisement was presented as a real demonstration of Volvo's superior construction, but the results had been rigged by reinforcing the Volvo.' Kim Foltz, 'The Media Business: Advertising; Scali Quits Volvo Account, Citing Faked Commercial', The New York Times, 14 November 1990. 


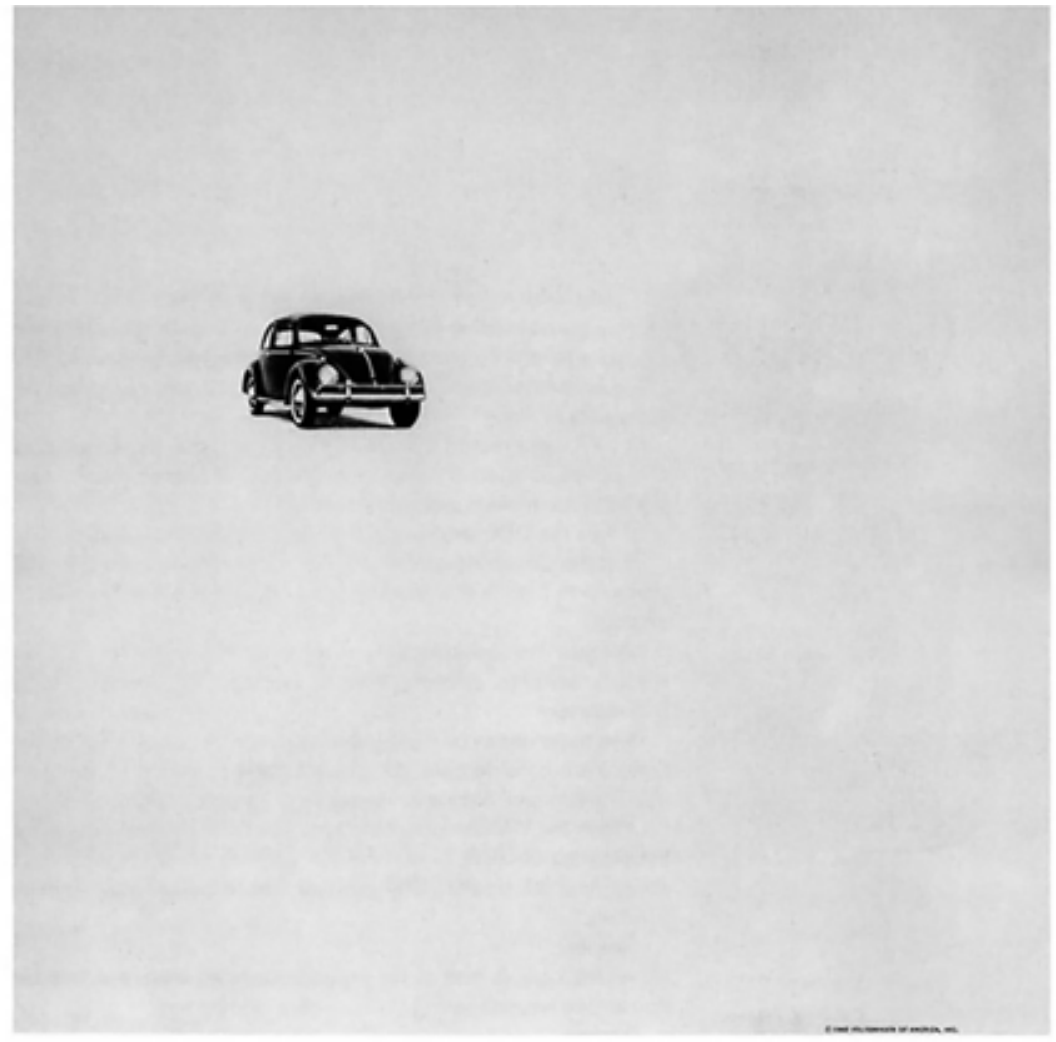

Think small.

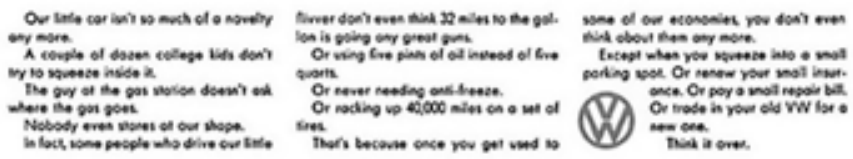

Figure 8.1: Ad for Volkswagen by DDB, 1959.

the human skeleton. The ad ends with a voice-over saying, 'Drive a Volvo, because replacement parts are hard to find', and a text, 'Volvo - A car you can believe in', together with an image of a stationary Volvo car. Though the car itself is stationary, the ad as a whole is constantly in motion, both through the camera and through the rotating parts of the skeleton, thus playing with the ideas of mobility and stability through the double entendre of 'replacement parts'. This car commercial also constitutes an early example of an ad in which the car itself is absent until the very last image. 


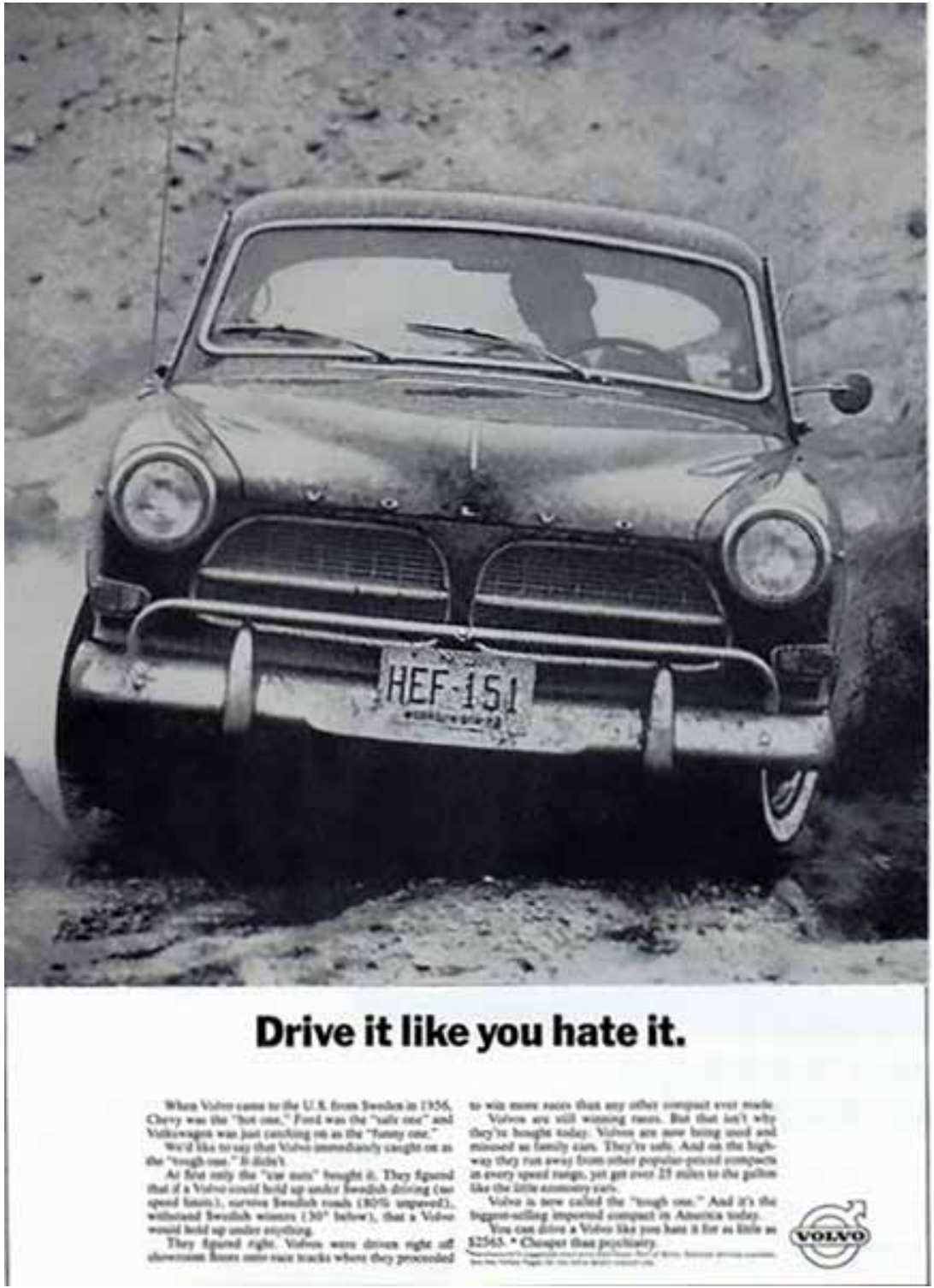

Figure 8.2: Ad for Volvo by Carl Ally Inc., 1962.

In 1991, Messner Vetere Berger McNamee Schmetterer, later MVBMs/Euro RSCG, took over, and was responsible for an important part of the company's international ads until 2014 in different collaborations. From 2007, for example, they collaborated with Arnold Worldwide, part of Havas, an advertisting agency, in which Euro RSCG is also included. During this period, according to the same article in AdAge, Volvo also completely shifted its media focus to TV. From a 
Swedish or Scandinavian perspective, however, there was a radical change as, according to Swedish journalist Bengt Carlsson, 'in 1994, Volvo gathered many of its ads, which at that time were spread across several agencies, within Forsman \& Bodenfors' 35 Though mainly responsible for the Swedish, Nordic, or European market, they have also been working on a global basis, parallel to MVBMS/Euro RSCG. In 2014, Grey London took over the international market.

\section{Different Agencies - Different Strategies?}

Examples from the different advertising agencies point to clear changes in strategies. Through the following selected examples, I will analyse some of the changes that occurred across the three different ownerships of the company and consequently also the varying ad agencies. The two different advertising theories, hard sell and soft sell, should also be kept in mind here: to what extent can they be traced throughout these strategic changes?

In 'Survivors' (1994), produced by MVBMS/EuroRSCG, eight scenes from different everyday environments are shown, all with distinctly named persons in different configurations: family, woman, couple, man, couple, three men, couple, two women. These 'survivors' are in movement: jogging, playing sports, dancing, fishing... The shots are accompanied on the soundtrack by tones of a moving carol, 'What Sweeter Music', arranged by John Rutter and performed by the Cambridge Singers. Thereafter, a voice-over solemnly announces that ' $[t]$ he people you've been looking at, all share a common belief, that a car saved their lives'. At the end, there is a slogan: 'Volvo. Drive Safely', but no car is visible whatsoever.

In 1997, Forsman \& Bodenfors produced 'The Golfer', an ad for the new Volvo V7o Bi-fuel. The soundtrack includes a song by the Ink Spots from the 1940s, 'Whispering Grass (Don't tell the Trees)'. On the image track in 'The Golfer', movement is once again in focus. Two golfers are shown. The first makes a perfect strike, and the ball lands only a short distance from the hole. His satisfied 'Hmm', following this achievement, is quite clear. The second man makes his strike, and the ball bounces, like in a pinball machine, between the trees, only to end up with a hole-in-one. He hums back. Then we see him putting the equipment into the boot. Here, the camera focusses on the 'Bi-fuel' on the car, which suggests that the car is environmentally friendly, and which immediately links to the slogan: 'One

35 Bengt Carlsson, 'Kreativiteten flyttad till Göteborg. Svensk reklambyråundersökning. Varumärkesbyggarna Forsman och Bodenfors högst rankad I landet', DNEkonomi, 8 (December 1996). 
day nature will thank you.' The car - visible for the first time, in the last ten seconds of the ad - starts moving just at the end. The very structure of the ad thus suggests a respect for nature, where the car has only a limited, albeit important, role. In this highly visual ad, as well as in other ads from Forsman \& Bodenfors, there are no real arguments, but rather slogans that connect to the highly visual advertising strategies.

Three years later, in 2000, Euro RSCG produced 'Saturday' for the Volvo V7o Turbo. This ad tells a story that takes place in two locations simultaneously, as a father dashes back and forth, constantly moving between his two children's sports events: his son's swimming competition as well as his daughter's football match. The background music is 'Get a move on' by Mr. Scruff. 'Thank heaven for Turbos. It's all about family', the speaker tells us.

The similarity with Forsman \& Bodenfors's 'Toast' for Volvo V7o (2000) is striking: the husband is preparing breakfast, and after having found out that there is no more butter, he quickly leaves and returns just in time to watch the bread pop out of the toaster. One great difference is the car movement. In 'Saturday', the car is present in the ad about half of the time, and is almost always in movement. In 'Toast', on the other hand, the car is only present for a few seconds, mostly in arrest, and when it is moving, it is barely visible because it drives too fast. Another great difference is that, whereas Euro RSCG uses a lot of spoken argument, the 'Toast' ad is just accompanied by music and the simple slogan ' 250 HP. o to 100 in 7.1 seconds'. That is also a general conclusion concerning Euro RSCG - they use more arguments, both spoken and written.

Through the Arnold agency, in 'Wheels' (2007), four of the Volvo $\mathrm{XC}_{70}$ crossover's qualities are addressed, using the melody of the popular children's song 'The Wheels on the Bus'. The first verse goes: 'The wheels on the car go round and round', referring to the fact that the car is equipped with all-wheel drive (AWD), but also that the car is generally durable, and the ad shows a couple driving in mountain scenery. The second verse goes: 'The power tailgate goes up and down, up and down', and we see the car stop to pick up a mountaineer, and his backpack goes into the boot, pointing out the automatic tailgate.

After that, the car goes downhill and the song goes: 'The hill descent control goes nice and slow, nice and slow', which means that the car has an automatic descent control that makes the car go nice and slow, without using the brakes. The final verse - 'There is room in the car for everyone, everyone' - and the car stops again, this time picking up two more mountaineers. Here, just like in the previous ads, it is clear that the car enables other kinds of movement, such as climbing or hiking. The ad then ends with the slogan 'Life is better lived together'. Arnold's ads generally use the 
soundtrack to make arguments - in this one, by the song, although in other examples by spoken words.

The first ad by Grey London was 'The Swell' (2014) for the Volvo XC6o, and it used a kind of 'horror film' aesthetic to deliver the message. An empty car is parked on the beach, the doors are open, the lights are still on, and so is the radio, broadcasting - in Swedish - a forecast that predicts bad weather. From inside, the camera slowly moves in one long take: out and around the car, down along the sand, and out into the sea. At the same time, a dark voice says: 'To feel, to really feel, is a rare thing these days.' The ad continues under the sea and rises up, revealing a woman sitting on a surfboard - the camera comes closer, gets swallowed by a wave, and comes up again, showing the woman lying on the board surfing on a wave. Once again, in addition to the aesthetics, the car is associated with the possibility to gain access to other kinds of movement - and in this case, also to get away if needed. Then the ad abruptly goes black and the text 'SEEK FEELING' is thrown right into our eyes, and after that 'The Responsive XC6o'.

From this survey, it is possible to trace two main types of contemporary advertising films for Volvo. There may of course be variations in local or national agencies, but two tendencies nevertheless stand out. On one hand, the American or global form of ad, represented by MVBMs/Euro RSCG or Arnold, features arguments made both on the soundtrack and through texts on the image track, and cars are often shown in movement. On the other hand, the Swedish formula, as represented by Forsman \& Bodenfors, displays no argument save for a discreet and subtle slogan..$^{6}$ Their ads mostly feature a stationary car, and their emphasis is thus not on movements of the car, but rather on movement itself, to allude to something that the car is able to do. Grey London seems to take a position somewhat in between these two different strands. From what they have produced so far, there is a strong connection to the cinematic and to film history. ${ }^{37}$

36 The aforementioned ad campaign by British AмV ввDо ('Fog' and 'Kids', 1999) and a campaign for Volvo S6o by McCann Tel Aviv (2008) with the slogan 'It will take you time to realize it's really yours' are also examples of this kind of more discreet methods. All these ads were made for potential use both in cinema and on television, though I have not gone into detail in exploring the actual uses.

37 It is interesting to compare with the development in print ads, as described by Werner: 'That the image dominates over the text has to do with the view of branding as a largely visual strategy. It is supposed to be easier for the consumers to take in visual material and incorporate it into their own dreams and visions. At the same time, this makes many demands on the visual material: it has to open up towards the longings and fantasies of many different people. The environments in which the cars and the people are situated are therefore general in their character. There are coastal villages, downtowns, deserts, mountains and winter landscapes.' 
It is also obvious that, in spite of varying ownerships or ad agencies, all of these commercials seem to work within the soft-sell tradition, using 'clever concepts, puns, humor, and visually arresting imagery'. Perhaps, though, the Arnold commercial 'Wheels' could be seen as an exception, a hybrid between hard and soft sell, which - even if it is done in a humorous way - argues for both by explicitly showing the different advantages of the car and by using the text in the song as a parallel argument.

Thus, the history of Volvo commercials also clearly shows that there is no such thing as a 'Volvo shot' reappearing throughout the decades and across agencies. Rather, it would be possible to single out, for example, a typical 'Forsman \& Bodenfors shot'; that is, the agencies have their own distinct profiles and also to a large extent form the images of the products they advertise.

At the same time, as we have seen, many aspects unite all of these films. There are common themes, such as the concept of Volvo as a lifestyle or the central role of nature, but there are also more specific images that reoccur. We have already seen how 'Made by Sweden' with Zlatan Ibrahimović echoes 'Sauna'. This could, of course, be pure coincidence, but as it turns out, there are a number of similar examples. Lighthouses - if not specifically Swedish, at least reoccur in Swedish imagery - appear in 'Cabriolet' (1998) by мvвмS/ Euro RSCG, as well as in Forsman \& Bodenfors's 'Leave the World Behind' (2013) and in 'The Connected Car' (2014) by MPG (Havens).

This shows how agencies, in their Volvo ads, work in a 'classicist' way; 'classicist' in the sense of their searching for imagery and displaying their creativity within an already established aesthetic framework, rather than trying to create something really new. That this makes agencies look back at earlier ads is demonstrated with extreme clarity in an ad by Forsman \& Bodenfors, the film 'Tomorrow's Classics' for Volvo S6o (2006). The film is built up as a classic split-screen film. To the left, there is an old ad for Volvo Amazon (1960), which drives around in a shifting landscape. To the right, in parallel, an updated version with a Volvo S6o shown in a similar landscape. Towards the end of the film, as both cars are driving towards the camera, the new car to the right steps on the gas and leaves the Amazon behind. Now, the right part of the image takes over completely, and the text 'Introducing tomorrow's classics' appears on the screen. The new car has overtaken the old, but they share the quality of classics, of yesterday and tomorrow. ${ }^{38}$

38 The Volvo home page, under the label 'Heritage', states: 'LOOKING BACK HELPS US LOOK FORWARD - We're still building on our legendary heritage', http://www.volvocars.com/intl/ about/our-company/heritage (last accessed 6 April 2021). 


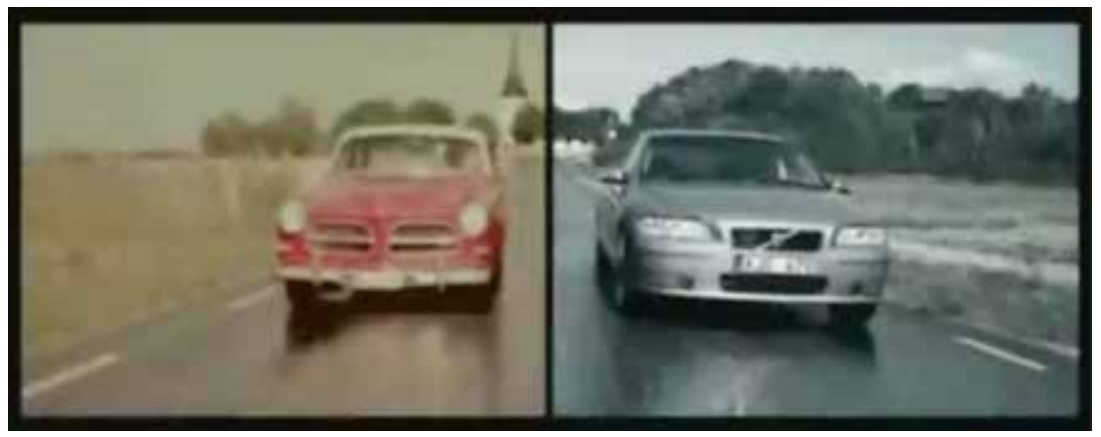

Figure 8.3: 'Tomorrow's Classics', screen ad for Volvo by Forsman \& Bodenfors, 2006.

Volvo's agencies do not only look at their own heritage; other car brands and other media are also used. An example is the British AMV BBDo commercial 'Fog' (1999), with a foggy landscape and only the car headlights visible - and the text 'The Volvo V4o/voted the world's most beautiful estate car/but sometimes looks aren't everything'. This ad obviously refers to DDB's famous Beetle campaign from the early 196os, with print ads like 'We finally came up with a beautiful picture of a Volkswagen', in which the only sign of the car is the tracks that it has made in the winter landscape that is shown, or the 'No point showing the '62 Volkswagen. It still looks the same', with a totally white paper replacing a picture. The history of advertising, across brands as well as across media, thus forms a common framework in which references and self-references frequently appear. The question of reference and self-reference is further elaborated in Yvonne Zimmermann's chapter 'Advertising's Self-Reference: From Early Cinema to the Super Bowl' in this book.

\section{Widening the Concept of Mobility}

If the car as moving object was highlighted in earlier film ads, this has changed quite radically throughout the decades. An important change in emphasis, as we have seen, is that from hard sell to soft sell, from the car and its specific qualities to more general questions of lifestyle and values. From the movement of the car as such, there is also an increasing switch towards the mobile life that the car enables: it takes you places you would never have dreamed of. The car now rather appears as a metonymy for mobility in life.

At the same time, cinematic movement as such is also used as a way to highlight mobility, and as a displacement in which the movement of the car is rather expressed through other images in movement. This reduces the 
redundancy of showing the car as moving, and instead introduces a rich variety of references to the history of moving images, including the theoretical assumptions from the beginning of the film medium qua movement. Interestingly enough, some of the ads from the turn of the millennium onwards - following the centenary of cinema - also seem to nourish a certain cinematic nostalgia in their references to film history, as in 'The Swell'. It is worth noticing that this nostalgic movement backwards is paradoxically combined with the fact that the ads today are mainly spread through the internet, using 'friendvertising' as a means to communicate their message. Thus, advertising itself has taken on a new kind of mobility as well. ${ }^{39}$

The ads for Volvo $\mathrm{C}_{70}$ Cabriolet produced by MvBMs/Euro RSCG from 1998 provide an earlier example of the same trend. A car drives through a mobile, urban landscape, with huge billboard ads for Volvo, shown in split-screen image together with the car. The people in the ads are moving, as are many objects in shop windows: a frock, a violin, a pair of shoes. In spite of the more advanced technology, the aesthetics here are quite similar to silent cinema's celebrations of mobility, as already mentioned initially in connection with early cinema and animation. ${ }^{40}$ The song on the soundtrack states that 'it's magic time', also alluding to early cinema's alignment with magic, from Méliès onwards.

The common final slogan of these films states: 'It will move you in ways Volvo never has.' These ads thus also introduce the idea of movement that is not only physical but also imaginary, of which 'Survivors' is another example. Through Volvo, the film ads throughout the decades seem to conclude that there are always possibilities for moving and for being moved in new and unexpected directions.

Would it then be possible to draw some kind of general conclusion from all these observations on movement in Volvo ads? Jean-Louis Schefer asks the rhetorical question, also suggesting a meta dimension to machines in cinema:

What, then, is a machine in cinema? Simply cinema itself which reveals its body, that is the system which drives movement? But cinema has no proper body, special or specific [...] The body of cinema is the succession and the montage of whatever, real or invented, is constituted as an image $[. ..] .^{41}$ 


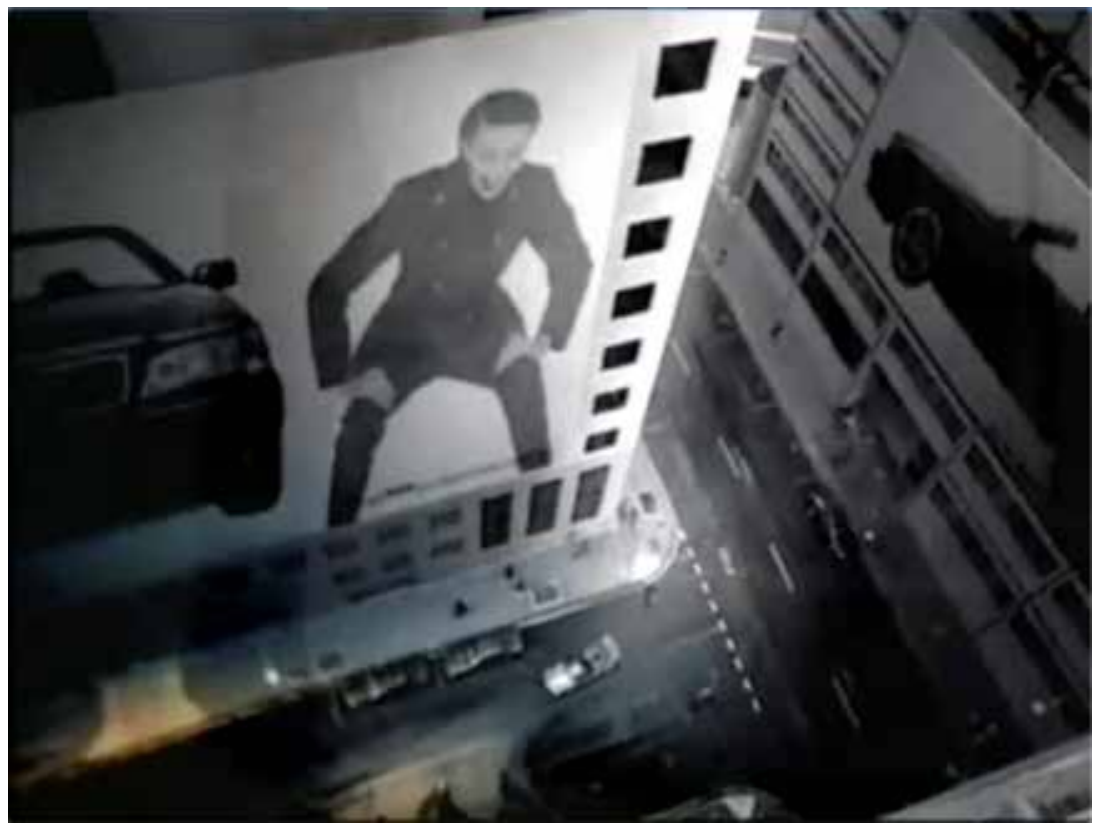

Figure 8.4: The moving person on the wall; the windows resemble the perforations on film stock. Screen ad for Volvo by MVBMS/EURO RSCG, 1998.

His conclusion, then, would be that both humans and machines in cinema are equally constituted as subjects, both belonging to the very movement of the image, as they take part in the same structure in which movement actually constitutes the image. Whether humans or machines, all are images; their lives and their movements together form the film. ${ }^{42}$

From moving cars to moving people and moving camera, the development of the dynamics of the Volvo ads thus actually reveals a meta dimension, albeit different from the one originally suggested by Schefer. By capturing all these movements in moving images and by gradually combining and multiplying their effects in increasingly complex patterns, these commercials actually all add to the basic capacity of cinema, to amaze and move its audiences, thus also introducing a new way of thinking within the movement, which can lead to changes in behaviour - indeed the very raison d'être for advertising films. 


\section{Bibliography}

Broberg, Oskar. 'Globalisering, entreprenörskap och humankapital.' Det svenska näringslivets historia 1864-2014, edited by Mats Larsson. Stockholm: Dialogos Förlag AB: 2014.

Florin, Bo, Nico de Klerk, and Patrick Vonderau, eds. Films That Sell: Moving Pictures and Advertising. London and New York: Palgrave, 2016.

Hediger, Vinzenz, and Patrick Vonderau, eds. Films that Work: Industrial Film and the Productivity of Media. Amsterdam: Amsterdam University Press, 2009.

Niss, Hanne. Made in Denmark. Nationalitetens betydning i internationalmarknadsføring. Aalborg: Aalborg Universitetsforlag 1994.

Schefer, Jean-Louis. Images mobiles. Paris: P.O.L. 1999.

Sivulka, Juliann. 'History: 1900-1920.' In The Advertising Age Encyclopedia of Advertising, vol. 2, edited by John McDonough and Karen Egolf. London: Fitzroy Dearborn Publishers, 2003.

Werner, Jeff. Medelvägens estetik, Sverigebilder i USA, Del 2. Hedemora: Gidlunds förlag 2008. 
